\title{
ANTIOXIDANT ACTIVITY OF SEAFENNEL (CRITHMUM MARITIMUM L.) ESSENTIAL OIL AND ROSE (ROSA CANINA) EXTRACT ON NATURAL OLIVE OIL
}

\author{
M. ÖZCAN \\ Department of Food Engineering, Faculty of Agriculture, Selçuk University, 42031 Konya. Turkey
}

(Received: 2 December 1999; 1 June 2000)

\begin{abstract}
The antioxidant effects of seafennel (Crithmum maritimum L.) essential oil and rose (Rosa canina) methanol extract at different concentrations were tested in natural olive oil stored at $60{ }^{\circ} \mathrm{C}$, by measuring peroxide values and free oil acidity after regular intervals. All concentrations of both plant extracts showed antioxidant effect compared with control in experiments. The most effective extracts were $0.4 \%$ level of rose. The $0.2 \%$ concentrations of rose extract and seafennel oil and $0.4 \%$ level of seafennel oil followed in a decreasing order, respectively. The $0.2 \%$ level of seafennel oil in olive oil had more effect than those of only $0.02 \%$ concentrations of butylated hydroxyanisole (BHA) and butylated hydroxytoluene (BHT). Acidity values of seafennel oil at the $0.4 \%$ concentration were high compared with its $0.2 \%$ level. Acidity values of both rose concentrations were found partly similar.
\end{abstract}

Keywords: antioxidative activity, seafennel, Crithmum maritimum L., essential oil, rose, Rosa canina, extract, herbs, olive oil, peroxide and acidity values

Seafennel (Chritmum maritimum L., Umbelliferae) is a small plant with succulent leaves and stems that grows wild along the Mediterranean coast in Turkey. The seafennel is a succulent, smooth, much-branched herb, woody at the base, growing freely on rocks on the sea-shore moistened by the salt spray. The whole plant is aromatic and has a powerful scent. Seafennel is widely used in modern perfumery and medicine. The tender leaves and stem tops can be eaten pickled in vinegar. Furthermore, the leaves and young branches are used in folk medicine for their antiscorbutic, carminative, diuretic, digestive, purgative and vermifuge properties (RUBERTO et al., 1991; BARRoso et al., 1991; 1992; Cunsolo et al., 1993; SENATORE \& DE FeO, 1994).

Rose (Brier hip, brier, rose, dogberry, dog rose, hep tree, hip fruit, hip tree, hop fruit, sweet brier, wild brier) are the fruits of Rosa genus in the Rosaceae family. Rosa canina is well known for its efficacy in strengthening the body's defences against infection and particularly the common cold. For thousands of years roses have been valued not only for their scent and flowers, but for their fruit as well. Today, rose hips 
are the major source of vitamin $\mathrm{C}$ in natural supplements, and labels often indicate this source. Furthermore, rose are rich in pectin, organic acids, essential oil and tannin. Rose is particularly beneficial for the digestive system, producing a diuretic effect without irritation of the kidneys (BAYTOP, 1984; ZHAO, 1988).

In recent years synthetic antioxidants are commonly used to prevent undesirable oxidation in many foods. The oxidation products of oils have toxic effects. Recently, these synthetic substances have been shown to enlarge the liver size and increase microsomal enzyme activity. So, there is a need for other substances to act as antioxidants and to prevent food oxidation (KAHL \& KAPPUS, 1993).

The search for and development of other antioxidants of natural origin are, therefore, highly desirable (LOLIGER \& WILLE, 1993; ÖzCAN \& AKGÜL, 1995a, b; GÜR \& GÜLDEN, 1997; ÖZCAN, 1999). Plant originated antioxidants have been used in oils or lipid containing foods in order to retard oxidative deterioration. The antioxidative activity depends on the solvent used, but the structure activity relationship of them have not been completely investigated (ChANG et al., 1977; BANLAS et al., 1992). The antioxidant activity of herb and its extracts is attributed to the phenolic components (CHEN et al., 1992).

So, the purpose of this study was to conduct experiments to prove their efficacy in olive oil and to compare it with commercial antioxidants BHA and BHT.

\section{Materials and methods}

\subsection{Materials}

Aerial parts of seafennel (Crithmum maritimum L.) were collected at random from plants growing along the seaside at Mersin (Büyükeceli-Gülnar) in Turkey in July 1998. Also, rose were collected from plants growing in Konya (Beyşehir) in October 1998. Plants were identified botanically at Biology Department of Selçuk University.

\subsection{Preparation of essential oil}

Fresh aerial parts of the plant ( $400 \mathrm{~g}$ ) were finely minced and hydrodistilled for $3 \mathrm{~h}$ with a Clevenger apparatus. The oil was dried over anhydrous sodium sulphate and kept in sealed dark bottles under cool conditions until used.

\subsection{Preparation of extract}

Ground rose fruit peel dried at air conditions was extracted with pure methanol (E-Merck, Darmstadt) for $3 \mathrm{~h}$ in a stirred vessel, at a liquid to solid ratio of 4:1 and at a 
temperature of $60{ }^{\circ} \mathrm{C}$. The mixture was filtered and concentrated in rotary evaporator and the solvent was completely removed. Extract was kept in sealed colour bottles under refrigeration until used.

\subsection{Olive oil}

Natural olive oil without adding any antioxidant was kindly supplied by Kristal company in Izmir. Its peroxide and acidity values were $13.04 \mathrm{meq} \mathrm{kg}^{-1}$ and $2.18 \%$, respectively.

\subsection{BHA and BHT}

Both synthetic antioxidants (Sigma) were preferred because of their common usage to retard the deterioration at oil company.

\subsection{Antioxidant activity measurement}

The rate of oxidation was monitored by periodic determination of peroxide values of the oil stored at $60^{\circ} \mathrm{C}$ by using methanol as extraction solvent. A calculated quantity of the BHA and BHT, essential oil, extract were added at the 0.02, 0.04, 0.2 and $0.4 \%$ concentrations into olive oil, and the mixture was stirred. A control sample was prepared under the same conditions without adding any antioxidant. All samples of $15 \mathrm{~g}$ were stored in $10 \times 100 \mathrm{~mm}$ open beakers at $60^{\circ} \mathrm{C}$ in the dark. For the peroxide number, a known weight of olive oil was dissolved in a mixture of acetic acid: chloroform $\left(\mathrm{CH}_{3} \mathrm{COOH}: \mathrm{CHCL}_{3}\right)(3: 2, \mathrm{v} / \mathrm{v})$, and saturated solution of $\mathrm{KI}(1 \mathrm{ml})$ was then added. The liberated iodine was titrated with sodium thiosulfate solution $(0.01 N)$ in the presence of starch as an indicator. Also, for the free oil acidity, a known weight of olive oil was dissolved in a mixture of diethyl ether: ethanol $(1: 1, \mathrm{v} / \mathrm{v})$. The mixture was titrated with potassium hydroxide with methanol $(0.1 N)$ in the presence of phenolphthalein as an indicator (A.O.C.S., 1989).

\subsection{Statistical analyses}

Findings of the research were analysed for statistical significance by analyses of variance (PÜSKÜLCÜ \& IKIZ, 1989).

\section{Results and discussion}

Antioxidant effects of seafennel essential oil and rose methanol extract prepared at different concentrations are given in Figs 1 and 2. 


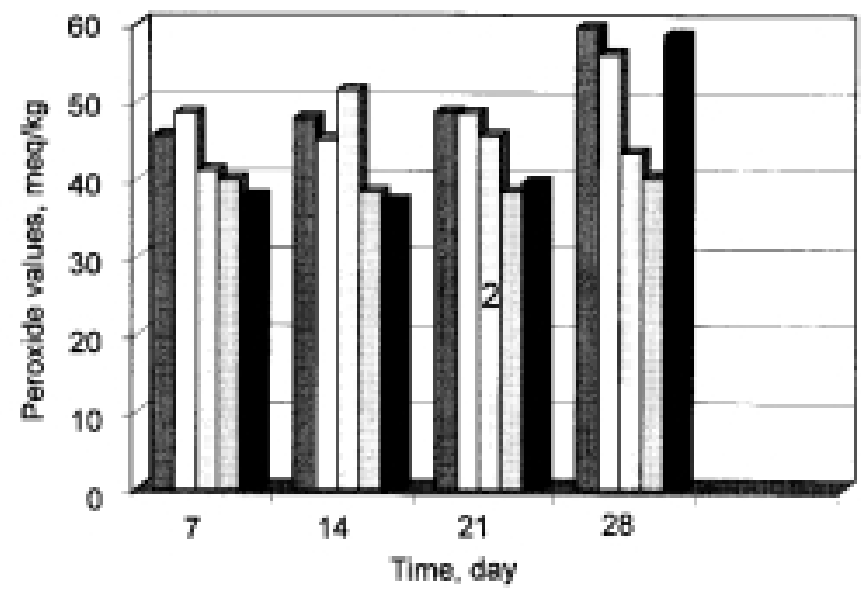

Fig. 1. Antioxidant activity of seafennel essential oil and rose extract. $\square$ Control; $\square$ BHA (0.02\%); $\square$ BHT (0.02\%); $\square$ seafennel $(0.2 \%) ; \quad$ rose $(0.2 \%)$

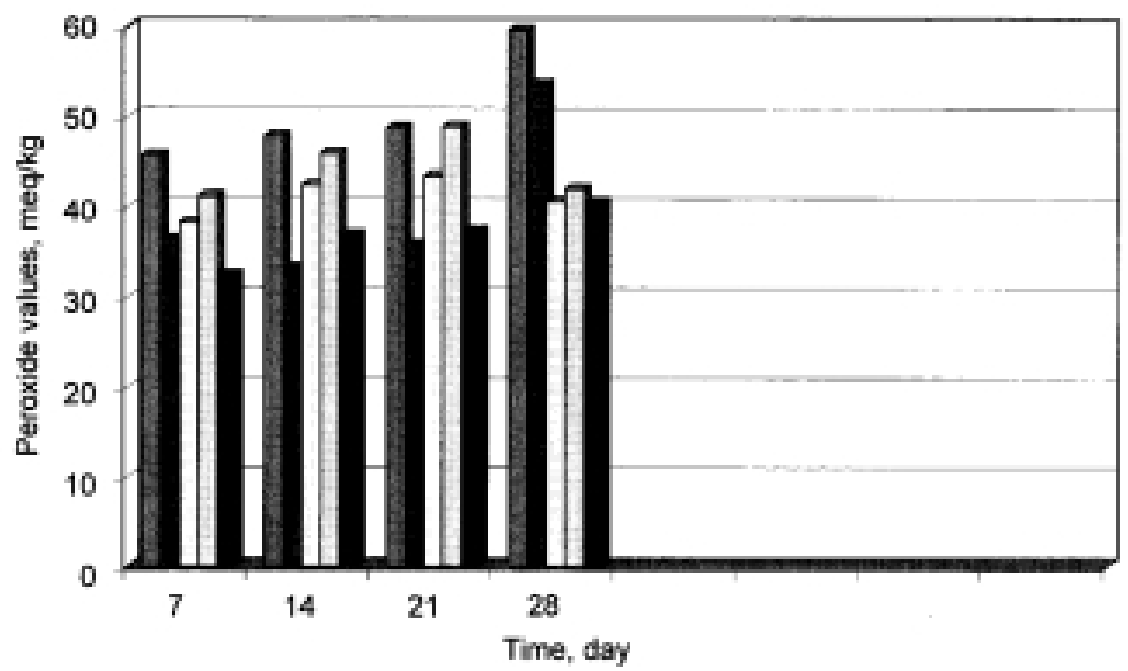

Fig. 2. Antioxidant activity of seafennel essential oil $(0.4 \%)$ and rose extract $(0.4 \%)$. $\square$ Control, $\square$ BHA $(0.04 \%) ; \square$ BHT $(0.04 \%) ; \square$ seafennel $(0.4 \%) ; \square$ rose $(0.4 \%)$ 


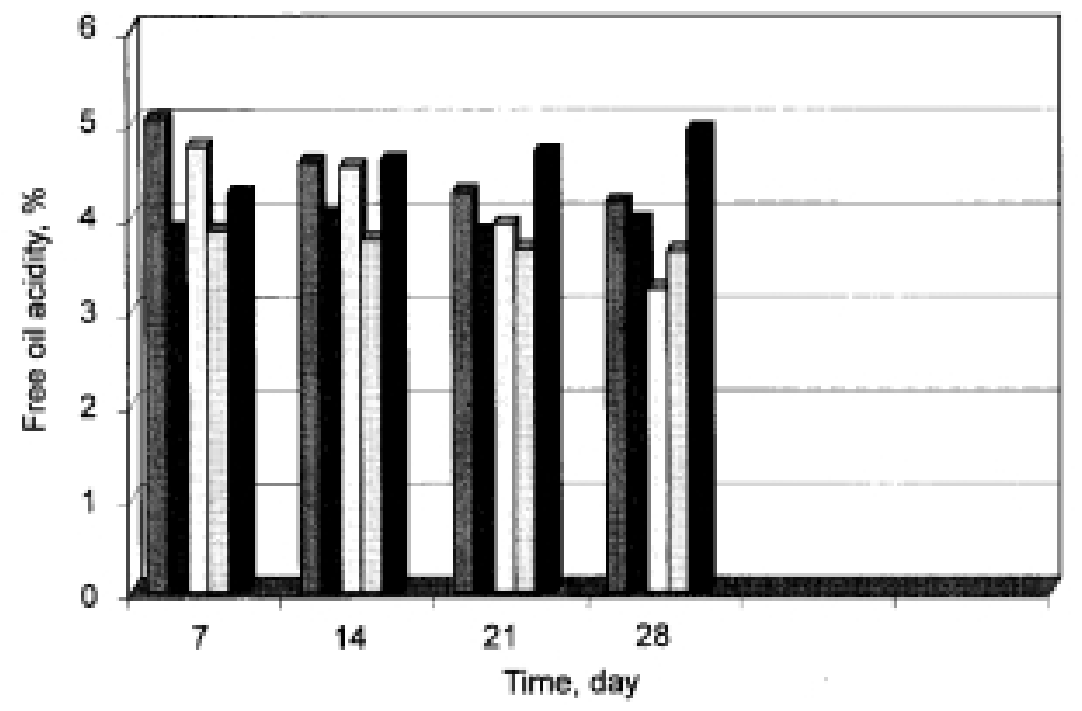

Fig. 3. Free oil acidity of seafennel essential oil $(0.2 \%)$ and rose extract $(0.2 \%)$. Control; $\square$. BHA (0.02\%); $\square$ BHT (0.02\%); $\square$ seafennel $(0.2 \% ; \square$ rose $(0.2 \%)$

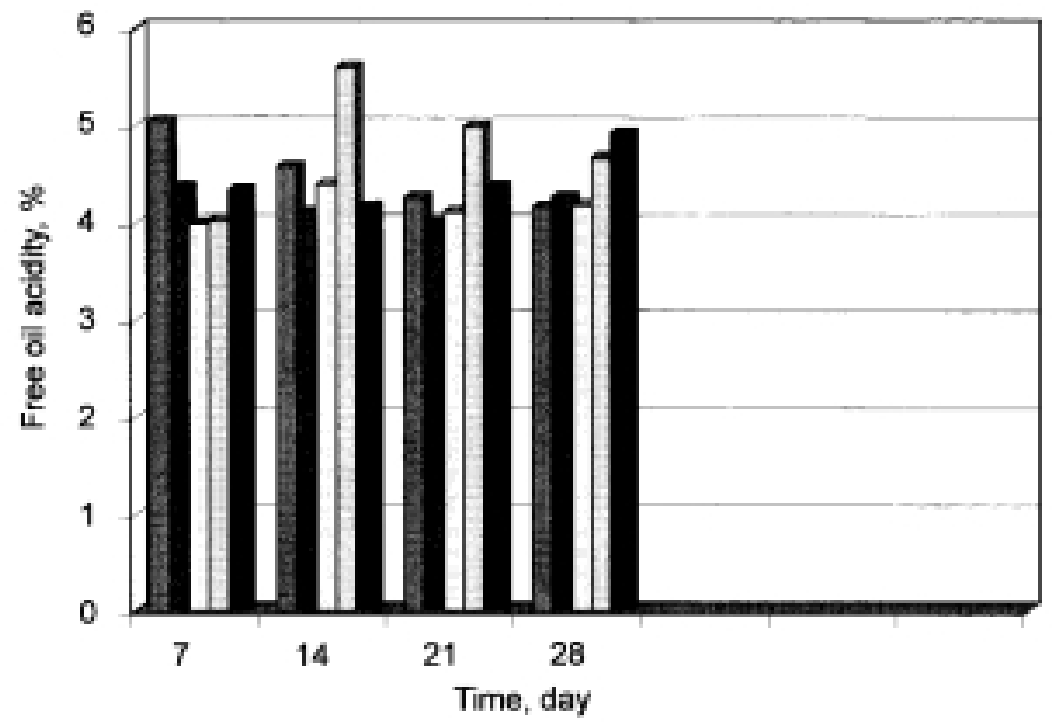

Fig. 4. Free oil acidity of seafennel essential oil $(0.4 \%)$ and rose extract $(0.4 \%)$. Control; $\square$. BHA (0.04\%); $\square$ BHT (0.04\%); $\square$ seafennel (0.4\%); $\square$ rose (0.4\%) 
All concentrations (except for $0.02 \%$ level of BHA and BHT on 7th and 14th day, respectively) exhibited antioxidant effect compared with control through the experiment (Fig. 1). The most effective antioxidant extract concentrations in a decreasing order (Fig. 2) were $0.4 \%$ level of rose, $0.2 \%$ of rose and seafennel and $0.4 \%$ level of seafennel oil. The $0.2 \%$ concentration of seafennel in olive oil had more effect than those of $0.04 \%$ level of BHA and BHT. However, $0.4 \%$ concentration of seafennel had higher antioxidant effect than that of $0.04 \%$ level of BHT (Fig. 2). Up to day 21, $0.2 \%$ concentration of rose extract maintained antioxidant activity in $0.2 \%$ level of seafennel oil. From then on their effects partly decreased.

Acidity values of seafennel oil and rose extract at different levels are given in Figs 3 and 4 . Acidity values of $0.4 \%$ concentration of seafennel oil were high compared to its $0.2 \%$ level. Linear relation of their acidity values with peroxide number was observed through the experiment. Acidity values of both rose concentrations were found similar. Acidity values of $0.4 \%$ level of seafennel oil were higher than those of $0.04 \%$ level of BHA (except for $0.04 \%$ level on day 7) and BHT (Fig. 4). Acidity values of $0.2 \%$ concentration of the same plant were as low as those of $0.02 \%$ concentrations of BHA and BHT (except for $0.02 \%$ level on day 28) (Fig. 3). Acidity value of $0.4 \%$ level of rose extract was low compared with control on day 21. Also, both concentrations of BHA and BHT (except for $0.04 \%$ level of BHA and BHT on day 28) showed low effect compared to control. The most effective substance preventing acidity increase was $0.02 \%$ level of seafennel oil. The potent action of rose extract is probably due to the presence of high amount of organic acids (ascorbic acid, citric acid, etc.), and attempts should be made to establish the related compounds and their effect, like in some other cases reported (BAYTOP, 1984).

Little is known about the extent to which the essential oils of spices may contribute to the antioxidant activity, although they have been extensively examined for their medicinal, culinary and antimicrobial properties (AKGÜL, 1993; ÖZCAN \& AKGÜL, 1995a). All these results indicated that the higher effects is owed rather to the phenolic $\mathrm{OH}$ groups than to the terpene alcohols and ketones because of the absence of aromaticity. The antioxidative activity displayed by spices or other antioxidants depends on several factors such as the concentration, the temperature, the hydrophobic or amphiphatic character, the presence of synergists and the chemical nature of the food or medium to which they are added (LOGOURI \& BOSKOU, 1995). Extract showed stronger activity than the seafennel essential oil. Further works should be made to establish the active substances of rose, and examine its synergistic effect together with other useful components. 


\section{Conclusions}

In this study, antioxidant effect of seafennel essential oil and rose extract in olive oil stored in dark at $60{ }^{\circ} \mathrm{C}$ was demonstrated. All concentrations of rose and seafennel exhibited antioxidant effect in varying rates compared with control through the experiment. Acidity values of both rose and seafennel concentrations were partly found similar. So, seafennel and rose can be used as natural antioxidants to prevent oxidation in plant oils.

\section{References}

AKGÜL, A. (1993): Baharat Bilimi ve Teknolojisi. (Spice science and technology.) Turkish Association Food Technologists Publ. No. 15, Ankara, Turkey.

A.O.C.S. (1989): Official methods and recommended practices. Vol. I, 4th ed., 2nd print. (including 1990 and 1992 additions and revisions). American Oil Chemists' Society, Champaign, ILL.

BANlAS, C., OREOPOUlOU, V. \& ThOMOPOUlOS, C. D. (1992): The effect of primary antioxidants and synergistics on the activity of plant extracts in lard. J. Am. Oil Chem. Soc., 69, 520-524.

Barroso, J. G., Pedro, L. G., PAIS, M. S. J. \& SCHEFFER, J. J. C. (1991): Analysis of the essential oil of Crithmum maritimum L. J. essent. Oil Res., 3, 313-316.

Barroso, J. G., Pedro, L. G., Figueiredo, A. C., PAis, M. S. J. \& SChefFer, J. J. C. (1992): Seasonal variation in the composition of the essential oil of Crithmum maritimum L. Flavour Fragr. J., 7, $147-150$.

BAYTOP, T. (1984): Türkiye 'de Bitkilerle Tedavi. (Treatment with plants in Turkey.) Istanbul Univ. Publ. No. 3255, Istanbul, Turkey.

ChANG, J. J., OSTRIC-MATIJAVIC, B., HSIEH, O. A. L. \& HUANG, C. L. (1977): Natural antioxidant from rosemary and sage. J. Fd. Sci., 42, 1102-1106.

CHEN, Q., SHI, H. \& HO, C.-T. (1992): Effects of rosemary extracts and major constituents on lipid oxidation and soybean lipoxygenase activity. J. Am. Oil Chem. Soc., 69, 999-1002.

Cunsolo, F., Ruberto, G., AMiCO, V. \& PiAtTelli, M. (1993): Bioactive metabolites from Sicilian marine fennel, Crithmum maritimum. J. nat. Prod., 56, 1598-1600.

GÜR, E. \& GÜLDEN, O. (1997): Oregana (Oreganum onites L.) ekstraktlarinin rafine zeytin yaǧindaki antioksidatif etkilerinin incelenmesi. (Antioxidative activity of oregano (Oreganum onites L.) extract in refined olive oil.) Gida Teknolojisi (Fd Technol.), 718, 56-64.

KAHL, R. \& KAPPUS, H. (1993): Toxikologie der synthetischen Antioxidantien BHA und BHT im Vergleich mit dem natürlichen Antioxidans Vitamin E. Z. Lebensmittelunters. -Forsch., 196, 329-338.

LOGOURI, V. \& BOSKOU, D. (1995): Screening for antioxidant activity of essential oils obtained from spices. -in: CHARAlOMBUS, G. (Ed.) Generation, analysis and process influence. Elsevier Science. B. V., London, pp. 869-879.

LOLIGER, J. \& WiLle, H. J. (1993): Natural antioxidants. Oils Fats int., 9, 18-22.

ÖZCAN, M. \& AKGÜL, A. (1995a): Antioxidant activity of extracts and essential oils from Turkish spices on sunflower oil. Acta Alimentaria, 24, 81-90. 
ÖZCAN, M. \& AKGÜL, A. (1995b): Baharat ekstraktlan ve uçucu yaglariyla Tenox 4 (BHA+BHT) ve sitrik asit kombinasyonlarinin ayçiçeǧi yaǧinda antioksidan etkileri. (Antioxidant effects of combinations of extracts and essential oils from Turkish spices with Tenox 4 (BHA+BHT) and citric acid on sunflower oil.) S. U. Agric. Fac. J., 8, 7-17.

ÖZCAN, M. (1999): Antioxidant activity of rosemary (Rosemarinus officinalis L.) extracts on natural olive and sesame oils. Grasas y Aceites, 50, 355-358.

PÜSKÜLCÜ, H. \& IKIZ, F. (1989): Istatistiğe Giriş.(Introduction to statistics.) Bilgehan Press, Bornova, Izmir, p. 333.

RUBERTO, G., BIONDI, D. \& PIATTELli, M. (1991): Composition of the volatile oil of Crithmum maritimum L., Flavour Fragr. J., 6, 121-123.

SENATORE, F. \& DE FEO, V. (1994): Essential oil of a possible new chemotype of Crithmum maritimum L. growing in Campania (Southern Italy). Flavour Fragr. J., 9, 305-307.

ZHAO, G. Y., HOU, A. W. \& GAO, F. T. (1988): Study on the change of vitamin C content of rose fruit during its storage and processing. J. North-East Forest. Un., 16, 102-105. 